\title{
Het Psalter als meerstemmige Thora
}

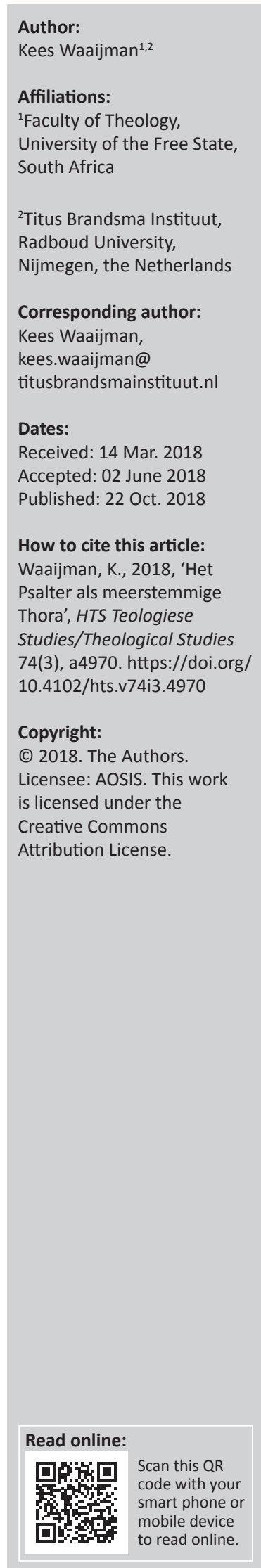

Psalm 1 is generally called the 'introduction' to the whole Psalter. At the same time this Psalm is defined as 'Torah Psalm' in a narrow sense. By this definition only a few psalms in the Psalter are really Torah Psalms. A 'Torah Psalm' as introduction to the Psalter may seem inappropriate. Is Psalm 1 perhaps the wrong 'introduction'? Alternatively, is our concept of 'Torah' inadequate? With this article the researcher attempts to answer these two related questions. Firstly, the concept of 'Torah' in the Bible and in the Psalter is reset. Secondly, the key concepts of Psalm 1 are reinterpreted. The outcome is: not only in the Bible and in the Psalter but also in Psalm 1 'Torah' is a multi-dimensional phenomenon. Thus understood, Psalm 1 is a perfect 'introduction' to the Psalter.

\section{Inleiding}

De meeste exegeten zijn het erover eens dat psalm 1 bedoeld is als inleiding op het Psalter. Tegelijkertijd gaat men ervan uit dat psalm 1 een 'thora-psalm' is. Deze twee uitgangspunten botsen nogal eens met elkaar. Want thora wordt in de uitleg van psalm 1 vaak ingevuld als: een 'schriftelijk gefixeerde grootheid' in deuteronom(ist)ische zin, bedoeld om gereciteerd en bestudeerd te worden (Kraus 1978:136; Childs 1979:513; Ravasi 1991:82). Maar is zo'n thora-psalm nog wel een inleiding op het Psalter? Alleen psalm 119 lijkt er nog echt bij te passen, samen met een kleine thora-hymne (Ps 19:8-11) en een paar thora-snippers (Ps 37:31; 40:9; 78:1; 105:45). Was psalm 1 misschien een verkeerde keuze als inleiding op het Psalter? Of verstaan wij de thora van psalm 1 te eenduidig en doorzien wij het meerstemmige thora-karakter van het Psalter niet?

Op deze vragen zoeken we een antwoord in deze bijdrage die ik met grote waardering opdraag aan mijn collega's Prof. Dr Celia Kourie en Prof. Dr Pieter de Villiers die beiden het vakgebied van de Bijbelse Spiritualiteit zo'n warm hart toedragen. Zie voor verkenningen van dit probleemveld Botha (2005), Weber (2007), Zenger (2010) en Lombaard (2014) met literatuur.

Drie opmerkingen vooraf. Eerst een etymologisch gegeven: de woordafleiding van thora - een psalmisch woord ${ }^{1}$ - is onzeker en helpt ons niet echt verder. Sommigen denken aan een 'wijzend' gebaar met de hand (jarah). Mede daarom, maar ook om de eenzijdige vertaling 'wet' te vermijden, wordt thora steeds vaker weergegeven met 'wijzing'. De vertaling zien we voor het eerst in de Die Schrift und ihre Verdeutschung van Buber en Rosenzweig (1936), en wordt daarna door verschillenden overgenomen (zie bijv. Kraus 1978:135-137; Liedke \& Petersen 1979:1032-1043). Wij sluiten ons hierbij aan. Onze eigenlijke reden is de vaststelling dat 'wijzing' het hele betekenisspectrum van thora dekt: aanwijzing, mededeling, bepaling, richtlijn, regel, beslissing, vonnis, onderwijs, onderricht. $^{2}$

Ten tweede, een semantisch gegeven. Aan het einde van zijn onderzoek naar het bijbelse thorabegrip concludeert García López (1995:631): ‘De verschillende connotaties en formuleringen van de term thora laten geen ruimte voor pogingen zijn betekenisspectrum in te perken. Thora is een complexe grootheid'. Dit veelzijdige betekenisspectrum geldt ook voor het Psalter: 'Het semantische spectrum van thora in de psalmen is niet eenduidig vast te stellen' (1995:618). Wij gaan van deze conclusies uit en percipiëren thora als een veelzijdig betekenisveld dat zich ontvouwt binnen uiteenlopende contexten: het onderricht in de wijsheid, de priesterlijk-liturgische praktijk, de profetische werking van Gods woord, de deuteronomische hervorming en de ballingschap, om ten slotte als een meerstemmig geheel samen te vloeien binnen de sfeer van de Tweede Tempel (García López 1995:597-637; vgl. Stec 2011:612-616).

Ten derde, het tetragrammaton JHWH vertalen wij met 'Wezer'. 'Jahwe' betekent: 'Hij weze er'. Door veelvuldig gebruik van deze zegenbede bij het binnentrekken van nieuwe weidegrond verzelfstandigde deze zich tot Godsnaam (Waaijman 1984).

1. Het woord komt 220 keer voor in Tanach, waarvan 36 keer in het Psalter, dat is 16.4 procent.

2.Zie hiervoor de Vries en te Winkel (1991), lemma 'wijzing'. 
In deze bijdrage onderzoeken wij de term thora in het Psalter tegen de achtergond van de bovengenoemde traditiestromen: wijsheid, liturgie en profetie, deuteronomische hervorming, ballingschap en Tweede Tempel. We letten daarbij niet enkel op inhoudelijke determinanten, maar ook - in lijn met het spiritualiteitsonderzoek (Waaijman 2010:643-684) - op de 'ongeschreven wetten' waaraan deze tradities zich houden.

Blijken zal dat de thora in het Psalter en de thora in psalm 1 beide een meerstemmige werkelijkheid zijn die nauwkeurig op elkaar aansluiten.

\section{De thora van de wijsheid}

Waarschijnlijk de oudste (Liedke \& Petersen 1979:1033-1035) en in ieder geval de meest verbreide vorm van thora was de opvoeding door moeder en vader (Spr 1:8; 4:1; 6:8) en in het verlengde daarvan het onderricht van de wijzen (Spr 3:1; 7:2; 13:14) (García López 1995:622-624). 'Wijzing' betekent binnen deze context het geheel van opvoeding, tucht, vorming en lering, gericht op 'kundigheid' (chokma) waarin kennis, onderscheiding, besef en vaardigheid samenkomen. Zie Von Rad (1970) voor vorm, inhoud en spiritualiteit van het wijsheidsonderricht.

Om zicht te krijgen op deze thora maken we onderscheid tussen leerstof en werkwijze: waarover gaat het onderricht in de wijsheid en wat is de ongeschreven wet waaraan dit onderwijs zich houdt.

Wat betreft de leerstof, daarover kunnen we kort zijn. Zij wordt gepresenteerd in de vorm van probleemvelden die het wel en wee van het dagelijks leven betreffen (Kraus 1978:6465): huwelijk en gezin, eigendom en voorzieningen, arbeid en sociale omgang, rechtspraak en politiek, enzovoort (Waaijman 2010:50-54). Deze leerstof wordt onderzocht met het oog op wijsheid. Zeker zo bepalend voor de thora van de wijzen was evenwel de ongeschreven wet waaraan dit onderricht in de wijsheid zich hield. Wij noemen zeven karakteristieken.

Ten eerste, het werken met contrasten: 'Zaken scherp tegenover elkaar stellen is een kenmerkend onderdeel van de argumentatie in de wijsheid' (García López 1995:623). Psalm 1 is een duidelijk voorbeeld van dit contrastdenken en zet wat dit betreft de toon. Het heeft het Psalter 'op een zodanige manier tot leervoordracht omgevormd, dat hierin beslissingen en onderscheidingen tot gestalte konden komen' (Kraus 1978:64).

Ten tweede, het denken in spreukvorm. Een 'spreuk' (masjal) is een tweeregelige uitspraak met een denkpauze in het midden waarin twee gegevens tegen elkaar in worden gedacht (Kraus 1978:64). Ze spiegelen elkaar: stemmen overeen, verschillen of vullen elkaar aan. Zo geven zij richting - thora - aan het denken van de leerling die tussen de beide vershelften staat. De spreukvorm (bicolon) heeft blijkens de oudste handschrifttradities heel het Psalter bepaald (Kraus 1978:63).
Ten derde, het werken met beelden. Beeld en werkelijkheid worden tegen elkaar in gedacht. Dit beeldend denken is overal in het Psalter aanwezig. Het maakt het lezen in de psalmen niet alleen leerzaam, maar bovenal aangenaam.

Ten vierde, het makarisme, het 'weltoffen' welkom in de leerkring (Kraus 1978:134), is 'een karakteristiek inleidingskenmerk van het onderricht in de wijsheid' (Kraus 1978:64-65). Wanneer psalm 1 - en dus het Psalter - opent met een makarisme, dan staat daarmee het Psalter van meet af aan in de toonaard van het wijsheidsonderricht.

Ten vijfde, een achttal psalmen is alfabetisch gebouwd (Ps 9-10; 25; 34; 37; 111; 112; 119; 145). Deze werkwijze komt uit het onderricht in de wijsheid (Kraus 1978:66). Drie elementen zijn hier bepalend: de tweeëntwintig letters van het alfabet zetten een omvattend kader uit waarbinnen een thematiek in 'een universeel omtrekkende beweging' wordt ontwikkeld (Seybold 2003:253). Binnen dit omvattende kader wordt een vraagstuk systematisch behandeld. Het tekstlint van het alfabet reikt de leerling een leidraad aan waarlangs hij de ontvouwde ervaringskern kan overdenken (Waaijman 2012:33-43).

Ten zesde, een vragende houding: waarom, hoeveel, hoelang, wie, wat, waar? Aan deze vragen zit een zakelijke kant: zij beogen informatie. Maar ze zijn altijd ook gevoelsmatig georkestreerd: verwondering, verwijt, ongeduld, opstandigheid, verzet, angst, bezorgdheid, niet weten, vertwijfeling. Van deze vragende houding geldt wat van het werkwoord 'vragen' geldt: vragen veronderstelt en bewerkt beweging (Wagner 1977:314). Wie vraagt verlaat de comfortzone en waagt zich in het onzekere gebied van het niet-weten: behoefte aan kennis, speelruimte in relaties en de kwetsbare werkelijkheid van verlangen, bekommernis en zorg (Gerleman \& Ruprecht 1978:460-467). Verschillende psalmen openen met een vraagzin (zie bijv. Ps $2 ; 3 ; 13 ; 15 ; 22$; $52 ; 58 ; 74 ; 84)$.

Ten slotte, wijzen en onderwijzen. Binnen de context van het vragen spelen wijzen en onderwijzen een richtinggevende rol: aandacht trekken, concentratie bevorderen, uitnodigen het standpunt van de aanwijzer te delen, oefenen in perspectiefwisseling. Daartoe wordt in het wijsheidsonderricht frequent gebruik gemaakt van aanwijzende woorden als 'dit', 'ja', 'zo', 'hier'. Wijsheidsonderricht is wijzing (Wagner 1982:921). Het is niet vreemd dat een psalm meer dan eens deiktisch begint (Ps 12; 49; 106; 107; 118; 133; 134; 136; 144).

We vatten samen: de 'didactische inslag' van de wijsheid die de grondkleur van het Psalter bepaalt (Kraus 1978:63-66; Von Rad 1970:153-165), betreft niet alleen de inhoud van dit onderricht en zijn uitdrukkelijke gerichtheid op wijsheid, maar ook de ongeschreven thora waaraan de psalmen zich houden: ze zijn 'doordrongen van wijsheid' en volgen haar werkwijze (Zenger 1998:43-45; zie Botha \& Potgieter 2010; Johnston \& Firth 2005, hfdst. 8 en 11). 


\section{Liturgische wijzing}

De liturgische thora vertegenwoordigt een andere traditie dan die waarin de wijsheid werd ontwikkeld. Zij omvat aanwijzingen voor priesters betreffende het gebied van offers (Lev 6-7), reinheid (Lev 13-14), heiligheid (Lev 26:44; Ez 44:23), rituele functies (Ez 43:1 - 44:26), onderricht (Deut 33:10; vgl. Jer 18:18) en rechtspraak (Deut 17:8-12) (García López 1995:604-607). De psalmenexegese heeft sinds de studies van Gunkel en Mowinckel veel aandacht besteed aan deze dimensie van de psalmen. Uit deze studies komt de liturgische thora naar voren als regelgeving met betrekking tot de eredienst: de afbakening van de cultus (heilig-profaan, openbaar-privé, officieel-informeel, groepen-subgroepen); de vorm van de rituelen (ritualia); de bezorging van teksten (creatie, redactie, stijl); de vaststelling van plaatsen (het heilige, het allerheiligste, binnenhof, altaar) en tijden (dag-, week-, maand-, jaarritme); de positie van de actanten (koning, priester, leviet, koorleider, zanger, instrumentalist) en hun bevoegdheden, vaardigheden en verplichtingen (aanstelling, beloning); de uitvoeringswijzen (op- en bijschriften) (Ridderbos 1976:234-279).

Zeker zo belangrijk als deze uitdrukkelijke regelgeving is de innerlijke sturing door de kernrite ${ }^{3}$ van Israëls eredienst. Hoe ziet die kernrite eruit? Om hem te zien moeten we door de veelvormige tradities heenkijken: de riten bij de randnomadische weidewisseling, de viering van de uittocht uit Egypte, de offercultus van de eerste tempel, de treurrituelen bij de ruïnes van de verwoeste tempel, de gebedspraktijken tijdens de ballingschap en in de diaspora, de bedevaarten en processies, de gebedspraktijk in de leerhuizen, de synagogale eredienst, de rituelen in de familiekring. Door al deze variabelen heen tekent zich deze kernrite af: het roepen van de naam Jahwe (qara' be-sjem jahweh) dat zijn oorsprong heeft in de randnomadische spiritualiteit (Waaijman 1984:48-59), maar vanaf de uittocht het hart van Israëls liturgie vormt (Besnard 1962:10, 108).

Deze kernrite - zonder analogie in de omringende wereld (Niles 1974:65-67) - heeft drie dimensies: het uitroepen van de naam in nood, het uitroepen van de naam in bevrijding en de hierin ontvangen Zelfmededeling van God. De eerste twee dimensies verwoorden de uitersten van een (antropologisch) continuüm: de naam roepen in nood: 'Wees er!' en de naam roepen in redding: 'Hij is er!'. De derde dimensie vormt het (spiritueel-dialogische) Gegenüber: de genadige Zelfmededeling: 'Ik wees er!' We geven een korte toelichting bij deze drie dimensies.

Noodklacht. Wezer zegt tegen Mozes: 'Ik heb het kreunend geschrei onder zijn onderdrukkers gehoord' (Ex 3:7). In dit 'kreunend geschrei' van de onderdrukte slaven in Egypte ligt heel de biddende dimensie van de naam 'Wezer' uitgedrukt. De rituele voltrekking van de naam maakt de kracht los waarom zij smeekt: 'Mijn verweer en deun is Wezer, Hij weze mij ter bevrijding' (Ex 15:2).

3.Zie voor dit concept Waaijman (2016:3-9).
Erkenning. Prototypisch voor het danklied in Israël is het lied van Mirjam: 'Bezing Wezer! Ja, trots is Hij, trots, het paard en zijn wagen schoot Hij in zee' (Ex 15:21). Dit lied, nog onder de indruk van de bevrijdende kracht van Wezer die de overmacht van farao trotseert, staat model voor de specifiek Israëlitische liedvorm (Crüsemann 1969:19-80). De oproep tot zingen en erkennen wordt gevolgd door het eigenlijke lied waarin de bevrijdende werking van Wezer wordt bezongen (Crüsemann 1969:83-154).

Zelfmededeling. Een zeer oude notitie zegt: 'Op elke plaats waar Ik mijn naam laat gedenken, zal Ik bij jou komen en jou zegenen' (Ex 20:24) (Sellin \& Fohrer 1969:147). Waar ook maar, met instemming van Wezer, de gedachtenis van de naam wordt voltrokken - 'Wees er!' en 'Hij is er!' - komt Wezer aanwezig: 'Ik wees er', waarbij Wezer zelf de actant is (vgl. Tromp 1980:7-9).

Na deze bondige beschrijving van de kernrite zoomen wij in op het Psalter. Claus Westermann stelt terecht, 'dat het Psalter slechts twee hoofdgenres omvat ... : klaagpsalmen en lofpsalmen' (Westermann 1976:455). Klacht en lof horen, antropologisch gezien, 'polair bij elkaar, dat wil zeggen: zij betreffen in hun polaire betrekking het hele menszijn', maar, spiritueel-dialogisch gezien, staat 'de mens in klacht en lof voor God' (Westermann 1976:455-456). De psalmen verwoorden dit coram Deo niet steeds uitdrukkelijk als Zelfmededeling. Dat is logisch, want wat er werkelijk gebeurt, gebeurt 'tijdens het gebed' (Westermann 1976:460). Wat exegeten de 'stemmingsomslag' noemen - de beginstemming (klacht, nood, smeekbede) slaat om in de eindstemming (verhoring, redding, dank, jubel) (Ridderbos 1991:35-36) - gebeurt in het bidden zelf. Dit is geen 'psychologisch' gebeuren of iets dat zich buiten het bidden om voltrekt (een heilsorakel, een offer, een Godswoord) (Ridderbos 1991:36), maar een 'spiritueel-dialogische' transformatie: 'Steeds verandert er (vanuit God) iets, en wel tijdens het gebed' (Westermann 1976:460).

De boven beschreven kernrite ligt als ongeschreven wet ten grondslag aan het Psalter. We beschrijven haar kort: eerst de noodklacht, daarna de erkenning, ten slotte de Zelfmededeling.

Noodklacht. Psalm 116 is paradigmatisch voor het 'roepen van de naam van Wezer' in doodsnood: 'De naam van Wezer roep ik: Ach, Wezer, laat toch mijn ziel ontsnappen' (Ps 116:4). De psalmist is in de greep van de dood (Ps 116:3). Daar voltrekt hij, ver van het heiligdom, het uitroepen van de naam (Niles 1974:76). Deze kernrite neemt in de psalmen verschillende vormen aan. Enkele voorbeelden:

Genees mij, Wezer (Ps 6:3).

Bestrijd, Wezer, wie mij bestrijden (Ps 35:1).

Hoelang, Wezer, blijf jij mij vergeten (Ps 13:2).

Wezer, wees mij te hulp (Ps 30:11).

Verlaat mij niet, Wezer (Ps 38:22).

Sta op, Wezer, bevrijd mij, mijn Machtige (Ps 3:8).

Schik mij, Wezer (Ps 7:9). 
Zo wordt telkens weer de naam uitgeroepen in nood: bij ziekte, armoede, onrecht, verlorenheid, gevangenschap. De grondbeweging van dit roepen is steeds toevertrouwen en overgave. Dat blijkt opnieuw uit psalm 116: 'Verknocht ben ik, ja, Wezer hoort mijn stem om genade smeken ... Ik hecht mij, ja, ik spreek' (Ps 116:1, 10).

Erkenning. Psalm 116 is eveneens een schoolvoorbeeld van het roepen van de naam in erkenning: 'De beker van de bevrijdingen hef ik en de naam van Wezer roep ik ... Het slachtmaal van erkenning slacht ik Jou en de naam van Wezer roep ik' (Ps 116:13, 17). De psalmist is gered uit de dood en roept in een danklied (toda) de naam uit. De psalm zelf is de rite waarin de erkenning wordt voltrokken: 'Van harte slacht ik een slachtmaal voor Jou, jouw naam erken ik' (Ps 54:8; zie ook Ps 9:3; 61:9; 80:19) (Niles 1974:92). Ook het roepen van de naam in erkenning neemt verschillende vormen aan. Enkele voorbeelden:

Ja, gehoord heeft Wezer mijn huilende stem,

gehoord heeft Wezer mijn genadesmeken,

Wezer neemt mijn bidden aan (Ps 6:10).

Bezingen wil ik Wezer, ja, Hij bejegent mij (Ps 13:6).

Jij hebt mij vergeven, Wezer (Ps 31:6).

Ik erken Wezer om zijn bewaring (Ps 7:18).

Aldus wordt op veelvormige wijze de naam uitgeroepen in erkenning. Het uitroepen van de naam is de rite waarin de bevrijdende werking van Wezer present wordt gesteld 'temidden van heel zijn volk' (Ps 116:14, 18).

Zelfmededeling. De verborgen keerzijde van deze (antropologische) polariteit noodklacht-erkenning is de (spiritueel-dialogische) Zelfmededeling: 'Ik wees er!' Het roepen van de bidder en het horen van Wezer zijn twee kanten van één gebeuren: 'Ga horen, vertellen wil ik al wie de Machtige schromen wat Hij mijn ziel gedaan heeft: Hem riep ik met mijn mond, Hem verhogen ligt onder mijn tong' (Ps 66:16-17). In sommige psalmen wordt deze verborgen keerzijde uitdrukkelijk verwoord. In psalm 91 bijvoorbeeld:

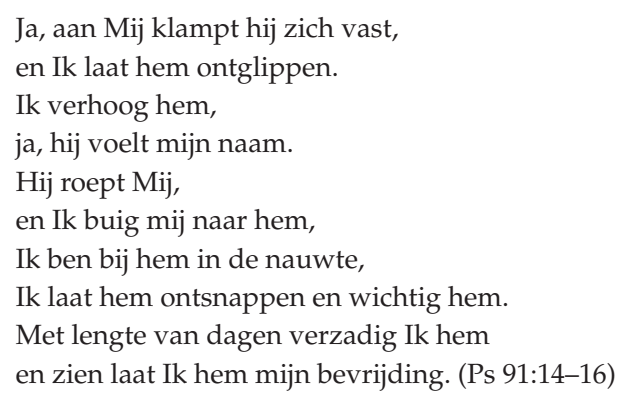

In dit Godswoord is duidelijk de (antropologische) polariteit zichtbaar: enerzijds zich biddend vastklampen aan de naam in nauwte en doodsnood; anderzijds ontglippen uit de nauwte, verhoogd en bevrijd worden. Het wezenlijke gebeurt in het roepen: 'Ja, hij voelt mijn naam; hij roept Mij, en Ik buig mij naar hem; Ik ben bij hem in de nauwte'.

Het roepen van de naam van Wezer is de kernrite waarin Wezer zichzelf meedeelt binnen het polaire spanningsveld van de twee hoofdgenres van de psalmen: noodklacht en erkenning. Deze kernrite die als ongeschreven thora aan het Psalter liturgisch richting geeft, wordt expliciet in imperatieven als: 'Vier. Erken. Zing. Joel. Roep'. Deze imperatieven maken de liturgische thora expliciet. Drie observaties bevestigen dit.

Eerste observatie: zesmaal (Ps 92; 106; 107; 118; 136; 147) wordt de oproep ondersteund door de motivatie dat het 'goed' is Wezer te erkennen: 'Goed is het te erkennen Wezer' (Ps 92:2; zie ook 147:1). Dit om twee redenen: de erkenning komt ons leven ten goede (Westermann 1978b:495; Westermann 1978c:675-679), maar tegelijkertijd: de erkenning deelt in de goedheid die Wezer is. Deze dubbel gemotiveerde erkenning is 'betamelijk' (Ps 33:1), dat wil zeggen: zij betaamt 'als religieuze verplichting ... voor de vrome dat hij JHWH de Hem toekomende lof moet zingen' (Beyse 1986:119).

Tweede waarneming: psalm 122 stelt dat de stammen van Israël samenkomen om 'de naam van Wezer te erkennen', met als motivatie: daarmee geven zij gestalte aan het 'gebod voor Israël' (Ps 122:4). Hier wordt de 'erkenning van Wezer' gezien 'als wet voor Israël' (Westermann 1978c:681).

Derde waarneming: 'Wezer vieren' om zijn heilige en heiligende aanwezigheid is volgens psalm 78 een 'wijzing in Israël' (Ps 78:4-5). Zie voor deze samenhangen Hossfeld en Zenger (2000:648).

We concluderen dat de liturgische thora van het Psalter de richtinggevende kracht van de kernrite volgt: het uitroepen van de naam (tussen smeekbede en lofprijzing) én de daarin ontvangen genadige Zelfmededeling. Deze kernrite is de ongeschreven liturgische wet van het Psalter.

\section{De profetische wijzing}

Een derde dimensie in de thora komt ter sprake bij de profeten, hoewel zij zichzelf niet als thora-experts beschouwden. Dat zijn volgens hen de priesters: 'Nooit ontbreekt een wijzing aan de priester, een raad aan de wijze, een aanspraak aan de profeet' (Jer 18:18; zie ook 2:8). Het woord thora komt dan ook betrekkelijk weinig voor bij de profeten: samen 44 keer, tegenover 36 keer in het Psalter. Dit betekent niet dat de thora hun niet interesseert (García López 1995:611-618). Integendeel, zij leggen slechts eigen accenten. Twee punten springen naar voren: de inhoudelijke bepaling van de profetische thora en haar spirituele dynamiek.

Wat de inhoudelijke component betreft, het richtsnoer van de profetische thora is gerechtigheid die twee kanten heeft: bewaring en schikking (Waaijman 1989:79-89). Bewaring is de groeizame sfeer waarin mensen en dingen gedijen en tot hun recht komen: 'Zoals de aarde haar gewas voortbrengt, zoals een tuin het zaad doet ontbloeien, zo doet Wezer, mijn Meester, uitbundige bewaring ontbloeien voor het oog van alle volken' (Jes 61:11). Bewaring laat mensen en dingen tot de waarheid van hun wezen komen. Schikking is het handwerk van de bewaring: interventies die ervoor zorgen 
dat mensen en dingen gedijen. Bewarend schikken als richtsnoer van de profetische thora (Jes 42:4) krijgt gestalte in het concrete leven en samenleven: procedures die de rechtsorde beschermen, regelingen die het samenleven in zijn voegen houden. De zwaksten, de alleenstaanden en de onderliggenden staan in de profetische thora centraal: 'Schik de zwakke en de wees, bewaar de gebogene en de arme' (Ps 82:3). In dit psalmvers wordt de profetische thora treffend verwoord (zie bij wijze van voorbeeld Ps $2 ; 12 ; 14 ; 50 ; 52 ; 53$; $58 ; 82 ; 140)$. Door heel het Psalter heen klinkt het verlangen naar bewarende schikkingen: de naties worden aangesproken op hun verantwoordelijkheid (Ps 2:1); de bevrijdende kracht van Wezer wordt ingeroepen tegen kwaadaardige onderdrukking en doemen (Ps 12:2; 14:1; 52:3; 53:2; 140:2); de rechters worden herinnerd aan hun primaire taak (Ps 58:2); de Machtige richt zich op in de zich goddelijk wanende samenklontering van Macht (Ps 82:1).

Wat betreft de spirituele dynamiek van de thora, zij is aanspraak (dabar) van Wezer. Bij de notie 'aanspraak' staat niet de inhoud, maar 'de activiteit van het spreken, het uiten van woorden en zinnen' op de voorgrond (Gerleman 1977:435). Aanspraak is van het begin tot het einde 'gesprek' (Schmidt 1977:106). De profeet weet zich onmiddellijk aangesproken door zijn Meester. Daarom zegt Amos: 'De leeuw brult, wie zal niet schromen? Mijn Meester, Wezer, spreekt, wie zal niet profeteren?' (Am 3:8). De aangesproken profeet geeft deze aanspraak door aan zijn leerlingen als thora: 'Bind het getuigenis toe, verzegel de wijzing in mijn leerlingen' (Jes 8:16; vgl. 30:9) (García López 1995:611-612). Een ware profeet zal de aanspraak van zijn Meester nooit verdraaien: 'Degenen bij wie mijn aanspraak is, zullen mijn aanspraken waarachtig spreken' (Jer 23:28). Jeremia gebruikt voor heel dit dabar-gebeuren het beeld van het vuur en de hamer: 'Is niet mijn aanspraak als een vuur aanspraak van Wezer - als een hamer die een steenrots vermorzelt?' (Jer 23:29). De profeet kan niet zwijgen: 'Wilde ik Hem niet gedenken en in zijn naam niet spreken, dan werd het in mijn hart een brandend vuur, opgesloten in mijn gebeente' (Jer 20:9).

Wij concluderen: de inhoudelijke thora van de profeten schikking en bewaring - bepaalt de oriëntatie van het Psalter. Maar bovenal is het Psalter een profetische thora in zover het de onmiddellijke bemiddeling van de aanspraak van Wezer is.

\section{De ene wijzing}

Vanuit de deuteronomische hervorming die in de zevende eeuw ontstond en ten tijde van koning Josia haar bloei beleefde, zet de idee zich door dat de thora een 'geschrift' is, een 'boek', 'het boek van de wijzing' (2 Kon 22) (García López 1995:607-611). De binnenkant van deze boekwording is eenheid (Waaijman 1984:101-110). Deze is op meerdere niveaus werkzaam. Allereerst, de ene en enige naam 'Wezer': 'Hoor, Israël, Wezer, onze Machtige, is één' (Deut 6:4) (Westermann 1981:37). Vervolgens, het ene heiligdom op de Sion waar de naam woont en wordt uitgeroepen, en waar het volk wordt verzameld (Rose 1975). Ten slotte, iedere Israëliet wordt één door liefdevol in betrekking met Wezer te treden: 'Je zult verknocht zijn met Wezer, je Machtige, met heel je hart en met heel je ziel en met heel je uiterste' (Deut 6:5) (Lohfink \& Bergman 1973:213).

Deze eenheid zoekende kracht van de deuteronomische hervorming is ook werkzaam in de eenheid van de geschreven thora:

een eenheid die, ook al is de bijbel geworden, uit vele en veelvuldige, hele en fragmentaire elementen samengegroeid, toch een echte, organische eenheid is en slechts als zodanig waarachtig begrepen kan worden. (Buber 1964:1185-1186)

Deze eenheid stuurt als een architectonisch concept de 'naar bijbelse eenheid strevende selectie- en coördinatie-arbeid' van de redacteuren (Buber 1964:1186).

In het Psalter weerspiegelt zich dit eenheidstichtende bewustzijn het meest welsprekend in de compositie van psalm 119, die bepaald wordt door de deuteronomische spiritualiteit (Waaijman 2012). De ene wijzing van Wezer ontvouwt zich hier in een alfabetisch kader waarin het achttal - teken van het meer dan volmaakte: zeven plus één, superlatief van de volheid (Hossfeld \& Zenger 2008:352) het ritme scandeert en waarin de acht grondwoorden van de ene thora worden ontvouwd: wijzing, getuigenissen, kommernissen, kerven, geboden, schikkingen, aanspraak, zegging. Zij vormen in hun herhaling en variatie - door Buber Leitwortstil genoemd (Buber 1962:20) - de mystiekdialogische kern van het gebedssnoer. Op deze manier is ieder vers de hele psalm, terwijl er tegelijkertijd geen enkel van de honderdzesenzeventig verzen gemist kan worden. Een geheimvol hologram van Wezer die in ieder vers biddend wordt aangesproken door de knecht en zich in ieder vers aan hem meedeelt als aanspraak en wijzing. Deze psalm is paradigmatisch voor de thora in de deuteronomische zin van het woord: hij richt de bidder van A tot $Z$ op de Ene, met heel zijn hart, met heel zijn ziel en 'met heel zijn uiterste'. Kedar-Kopfstein (zie 1984:611-613 voor de onderbouwing ervan) vertaalt 'mit deinen äussersten Anstrengung'.

Dat Wezer - de Ene en Enige - inderdaad het hart vormt van het Psalter als deuteronomische thora moge blijken uit twee waarnemingen. Ten eerste, de naam 'Wezer' is een psalmisch woord: de naam jah/jahwe die 6878 keer voorkomt in Tanach, komt 738 keer voor in het Psalter, dat is ruim 10 procent. ${ }^{4}$ Ten tweede, 'Wezer' komt opvallend vaak voor in de beginregels: 79 keer. Deze prominente plaats van de naam 'Wezer' in de psalmen geeft aan het Psalter een specifieke kleur: alles draait om de naam. Hij is de eerste en de laatste, de Ene en de Enige.

Wij vatten samen: het Psalter wordt uiterlijk (als geschrift) gevormd en innerlijk (als eenheid) gedragen door de deuteronomische thora in zover de verzamelende kracht van de ene naam daarin herkenbaar aanwezig is, onlosmakelijk 4. Het Psalter omvat 6.8 procent van de bijbel. 
verbonden met het gebod Wezer te beminnen met heel de persoon, tot het uiterste.

\section{De nieuwe wijzing in de ballingschap}

De verwoesting van Jeruzalem en de tempel in 587, het einde van het koningschap, de deportatie van de bovenlaag van het volk naar Babylonië, de ontheemding en de onverwachte terugkeer in 538 hebben in het bewustzijn van Israël een onuitwisbaar spoor achtergelaten, een 'kerf' (choq), vergelijkbaar met de holocaust in de recente geschiedenis. In de spirituele doorleving van deze afgang ontstond echter een 'nieuwe wijzing' (García López 1995:616-618). Het 'nieuwe' van deze thora bestaat in een radicale verinnerlijking: 'Hier mij' (hinneni).

'Nieuw' staat niet tegenover 'oud' en 'versleten', maar tegenover 'vroeger' en 'eerder' (Jes 42:9-10; 43:19; 48:6) waarin het 'nieuwe' niet werd vermoed. In het diepste duister van de ballingschap werd Wezer 'nieuw' ervaren: 'Slechts in de tijd van de ballingschap werd in Israël gesproken van iets "nieuws" in Gods geschiedenis, op geen enkele andere plaats in heel de geschiedenis' (Westermann 1978a:526).

Dit 'nieuwe' kwam voor de ballingen op verschillende manieren aan de oppervlakte: een vreemde macht (Kores) brengt bevrijding (Jes 44:24-45:7); er breekt een tijd van onvoorwaardelijke vergeving aan (Jes 43:22-28; Jer 31:34); het universele koningschap van God dient zich aan (Jes 45:20 25); iedereen is persoonlijk aansprakelijk voor zijn daden (Jer 31:29; Ez 18:2, 31); de omkeer wordt van beslissend belang (Klaagl 5:21) (North 1977:771-776).

Van dit 'nieuwe' is de 'nieuwe zang' die oprijst vanuit de catastrofe van de ballingschap, waarin alle 'zang' verstomde (Psalm 137), de verwoording (zie Brunert, Kleer \& Steins in Fabry et al. 1993:1264, 1266). Zij is het antwoord van de ballingen op het volkomen onverwachte 'nieuwe' doen van God (Westermann 1978a:529), de echo van zijn ongehoord 'nieuwe' presentie (Jes 42:10) (Westermann 1978a:529-530). In zangvorm ontstaat een nieuwe liturgische thora voor het gedesintegreerde volk (Stolz 1983; vgl. Millard 1994:27-29).

Deze thora-zang staat niet in steen gebeiteld of op perkament gekalligrafeerd, maar is de ballingen op het lijf geschreven en in het hart gegrift: 'Ik leg mijn wijzing in hun binnenste en schrijf haar op hun hart' (Jer 31:33). Deze thora is dus niet primair een uiterlijk boek of een uiterlijke rite; zij staat ingeschreven in het innerlijk van de persoon die ja zegt, in het hart dat zijn 'behagen' (Ps 1:2 en 40:9) vindt in het 'hier mij' van de knecht van Wezer (Waaijman 2004).

Wij concluderen: het Psalter rijst vanuit de ballingschap op als een 'nieuwe zang' voor zover de psalmen uiting geven aan de verinnerlijking van het Godscontact in het profetische 'hier mij' (hinneni). Dit proces van interiorisatie als 'nieuwe' godsdienstigheid maakt het aannemelijk dat het Psalter hier zijn eerste vorm ontving als plaatsvervanging van de tempelliturgie (Millard 1994:185, 189).

\section{De ene meerstemmige wijzing}

Wanneer Kores in 538 de Babyloniërs verslaat, geeft hij de ballingen toestemming terug te keren naar hun land. Ze mogen de stad Jeruzalem en de tempel herbouwen. In 515 wordt de Tweede Tempel ingewijd. Binnen zijn invloedssfeer komt een proces van wederopbouw op gang. De leiding in en rond de Tweede Tempel - gelegitimeerd in het Chronistisch Geschiedwerk - weet de verschillende stromingen te integreren binnen een open thora-begrip: 'Hieraan herkent men de integratieve stijl van de Chronist, zijn streven het geheel van de wil van God omvattend en tot in de kleinste details als thora te presenteren' (Fabry 1995:635). Hier wordt de spanwijdte van de thora in de na-exilische periode treffend verwoord: aan de ene kant de weidsheid van Gods wil die met koninklijke soevereiniteit zijn wijzing geeft; anderzijds de gedetailleerde regelgeving met het oog op de dagelijks praktijk. De spil waarom deze spanwijdte zich wendt en keert is de ene thora: 'Op basis van deze wet, die Ezra uit de ballingschap meebracht naar Jeruzalem (Ezra 7-8), moet de gemeenschap zich laten vormen (Ezra 10:3) door de echte tradities van Israël' (García López 1995:626). Ondanks alle hindernissen lukt het de nieuwe leiders Israël te verenigen rond deze thora als 'de horizon van de nieuwe levensinrichting van de gemeente' (García López 1995:627).

Diezelfde 'integratieve stijl' zien we in het Psalter. Wat betreft de spanwijdte van de thora, meteen in psalm 1 al wordt de toon gezet: enerzijds 'de algemene niet-technische betekenis van de "wijzing" in de betekenis van de geopenbaarde wil van JHWH' (v. 2a), anderzijds het 'thora-achtige "boek" dat tot mediteren geëigend is' en met toewijding wil worden gepraktiseerd in het dagelijks leven (v. 2b) (Seybold 1996:2829). De woorden 'behagen' en 'murmeren' bevestigen deze spanwijdte waarbinnen de verschillende aspecten van de psalmische thora hun plek vinden.

We laten - bij wijze van conclusie en samenvatting - zien hoe de thora in psalm 1 een vierklank is die zijn weerklank vindt in heel het Psalter: grondtoon is de eenheid zoekende gerichtheid; boventoon is de liturgische thora met haar centrum in het roepen van de naam; contrapunt is de profetisch-exilische spiritualiteit met als kern 'hier mij' (hinneni); tussentoon is de verbindende rol van de wijsheid met haar universele reikwijdte.

\section{De wet van de eenheid}

Wat in de deuteronomische hervorming begon - de ene naam Jahwe in het ene heiligdom op de Sion, uitgeroepen door het ene volk van Israël, levend vanuit de ene thora (zie Waaijman 1984:125-136) - wordt na de ballingschap de fundamentele dynamiek bij de wederopbouw. Het meest plastisch wordt deze dynamische eenheid verbeeld in de pelgrims die bijeenkomen in Jeruzalem. Zij zien het met eigen ogen: 'Jeruzalem, gebouwd als stad die zich tot eenheid heeft verzworen' (Ps 122:3). In hun bijeenkomen zijn de 
pelgrimerende stammen 'een getuigenis (een thora) voor Israël om de naam van Wezer te erkennen' (Ps 122:4). Diezelfde dynamische eenheid zien we in de gezamenlijke toeleg op de studie van de thora (zie Neh 8:5-7): de toeeigening van de thora wordt dé godsdienstoefening van het ene Israël, een vroomheidspraktijk die zich via de leerhuizen en synagogen zal verbreiden over heel het land en de diaspora (Safrai 1980:52-57). Deze dynamiek van pelgrimage en lering wordt gezien als universeel: 'De vele volken zullen gaan en zeggen: Kom, gaan wij naar de berg van Wezer, naar het huis van de Machtige van Jakob, opdat Hij ons zijn wegen leert en wij zijn paden gaan. Ja, uit Sion trekt de thora en de aanspraak van Wezer uit Jeruzalem' (Jes 2:3; Micha 4:2). Hier komen alle eenheidzoekende lijnen samen.

Deze alles dragende 'wet' van de eenheid is nawijsbaar werkzaam in het Psalter. Zij stemt de psalmen op elkaar af, versterkt de Leitwortstil, selecteert en voegt de afzonderlijke gedichten samen, schept spanningsbogen, clusters en duetten. Het meest duidelijk komt zij tot uitdrukking in het verzamelen en ordenen van eerdere psalmenclusters (Millard 1994:165-168). Dit proces vindt zijn afronding in de indeling van het Psalter in vijf boeken, 'de vijfdelige "Thora van David"' (Hossfeld \& Zenger 2008:24-26; Zenger 2010:17-65; Weber 2010:733-744). Het is immers David die zich in de receptie van de na-exilische gemeenschap profileert als bouwheer van de tempel en als inspirator van de liturgie. Hij ontpopt zich in de vijf boeken van het Psalter als nieuwe Mozes met een eigen liturgische thora.

Niet alleen in het Psalter - bij uitstek in psalm 1 die de psalmenverzameling inleidt - komt de volledige spanwijdte van de thora ter sprake: van het 'behagen in de wil van God' tot en met het 'liefdevol murmeren in het boek van de wijzing' (v. 2a en 2b). Want wanneer psalm 1 een thora-psalm is, dan niet alleen omdat hier met waardering wordt gesproken over de toegewijde bestudering van het 'boek', maar bovenal omdat de vrome zich met hart en ziel voegt naar de wil van zijn Meester in het concrete leven.

Zo is de grondtoon van de meerstemmige thora werkzaam in psalm 1 én in het Psalter: alle psalmen, hoe verschillend ook, zoeken hun passende plek in het ene Psalter dat zij samenkomend constitueren-als pelgrims: vanuit verschillende achtergronden komen zij samen om binnen de ene thora van Wezer (Ps 1) de Ene te naderen die woont op de Sion (Ps 2).

\section{De liturgische dominant}

Wanneer de eenheidzoekende thora de grondtoon van het Psalter is, dan voert de liturgische thora de boventoon, bovenal de naam die alles en allen verenigt (Ps 34:4), uitgeroepen in klacht en erkenning. Het epicentrum van dit roepen is het heiligdom op de Sion. Onder leiding van priesters en levieten is dit de belangrijkste institutie na de ballingschap. Deze thora wordt gelegitimeerd in het Chronistisch Geschiedwerk.

De liturgische thora laat zich zien in de interne schikking van het Psalter. Psalm 119 vormt niet langer het sluitstuk van het
Psalter (Westermann 1962:278-284). De op de Sion gerichte bedevaartpsalmen (Ps 120-134) en het Klein Hallel (Ps 146-150), inclusief enkele psalmen ertussen (met name Ps 135-136; 145), werken toe naar het slotakkoord van psalm 150. Deze psalm is liturgische thora bij uitstek, want hij bestaat uit puur imperatieven, zonder 'doorvoering', zelfs niet de meest eenvoudige: 'Ja, eeuwig zijn gunst' (vergelijk Ps 136). Deze liturgische dominant wordt bekroond wanneer het Psalter de titel 'Vieringen' (tehillim) krijgt.

Het Psalter als liturgische thora wordt bevestigd door Palestijnse teksttradities, daarin gevolgd door het Spaanse jodendom (Kraus 1978:2) die de derde afdeling van de Bijbel de Geschriften - laten beginnen met het boek Kronieken. Een sterk voorbeeld is de Codex Lenigradensis, de legger van de Biblia Hebraica Stuttgartensia (BHS) (zie hiervoor Millard 1994:241-242; zie ook Kraus 1978:2; Beckwith 1985:455 e.v.). Hierdoor staat het Psalter van meet af aan in liturgischDavidisch perspectief (Millard 1994:241). Nog sterker profileert zich deze davidische positie wanneer het boek Ruth voor het Psalter wordt geplaatst (Millard 1994:241-242).

Het slotakkoord van psalm 150 als liturgische thora klinkt reeds pianissimo in het openingsakkoord van psalm 1 , want 'murmeren' heeft de spanwijdte van de kernrite: het roepen van de naam in nood én erkenning (Negoita 1977:343-344, met de bemerking van Ringgren 1977:344-345). Wat betreft de noodklacht, de boekrol die de priester-profeet Ezechiël te eten krijgt, is aan beide zijden beschreven met 'klaagzangen: gemurmer en gejammer' (Ez 2:10; zie Ps 5:2). 'Murmeren' is hier 'jammeren'. Wat betreft de erkenning, 'murmeren' is ook vieren: 'Mijn tong murmert jouw bewaring, alle dag jouw viering' (Ps 35:28; zie ook Ps 63:6-7).

Zo is de liturgische boventoon van het Psalter van het begin tot het einde aanwezig in het roepen van de naam, in noodklacht en erkenning en in de daarin ervaren Zelfmededeling.

\section{Het exilisch-profetische contrapunt}

De boventoon van de liturgische thora ontmoet haar liturgische tegenstem in het exilisch-profetische contrapunt, dat niet 'na-cultisch' (Millard 1994:165, 209, 248, 250), maar 'kern-cultisch' is, want hier wordt Israëls eredienst teruggebracht tot haar kernrite: het roepen van de naam in doodsnood en bevrijding, met een diepe resonans in het profetische 'hier mij'. Het waren immers vooral de profeten die de ballingen door het nulpunt van de afbraak gidsten en taal gaven aan het onuitsprekelijke lijden van de armen. Hun stem bleef klinken in de periode van de Tweede Tempel als een 'nieuwe' profetische thora. Denken we maar aan de binnenbijbelse receptie van Deutero-Jesaja met zijn liederen over de knecht van Wezer (Berges 1999).

Binnen het Psalter is deze profetisch-exilische stem hoorbaar in de kringen die door het psalmboek worden aangeduid als: 'bewarenden' en 'gunstelingen', 'gebogenen' en 'behoeftigen', 
'beschroomden' en 'knechten' - allen dragers van de 'armentheologie' die het Psalter tot een profetische thora stempelt (zie hiervoor Berges 1999:14-27). Te beginnen bij psalm 1 wordt de bidder van het Psalter 'opgeroepen te kiezen voor de weg van de Thora, waardoor hij in de loop van de Psalmen (!) in de gemeente van de anawim en chassidim geïntegreerd raakt' (Berges 1999:21). Het zijn deze 'knechten van Wezer' die vanuit een armentheologisch perspectief formatief hebben ingewerkt op de eindredactie van het Psalter (Berges 1999:23; vgl. Hossfeld \& Zenger 1993:163).

Deze exilisch-profetische thora wordt kernachtig verwoord in psalm 40. Vanuit het verdwijnpunt van de ballingschap - 'de put van verwoesting, modderig slijk' - wordt een 'nieuwe zang' (Ps 40:4) in de mond van de psalmist gelegd (North 1977:774):

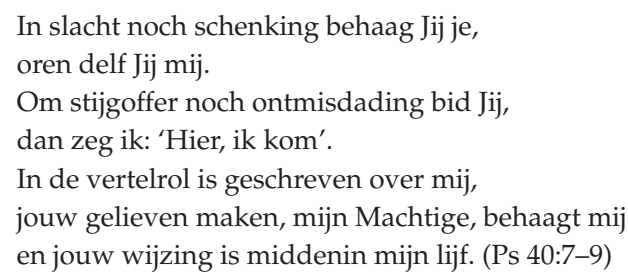

In deze 'nieuwe zang' komt een ongehoord nieuwe liturgie ter sprake: horen met 'oren' die 'opgedolven' zijn in 'de put van verwoesting', en het hart dat ja zegt: 'Hier mij'. Mijn persoon 'komt' als offerdier voor Gods gelaat, een schaap naar de slachtbank geleid, stil voor zijn scheerders. In deze thora is niet langer geschreven over eerderen en vroegeren (Jer 31:31-33), maar 'over mij' (Ps 40:8). Deze nieuwe thora wordt volkomen verinnerlijkt: zij staat 'middenin mijn lijf' gegrift (Ps 40:9). Deze interiorisatie vindt zijn uitbloei in de mystieke kennis: 'Dan hoeven ze elkaar niet meer te leren en de een niet meer tegen de ander te zeggen: Voel Wezer. Allen zullen zij Mij voelen, klein en groot - melding van Wezer' (Jer 31:34).

Deze 'nieuwe' thora komt reeds tot klinken in psalm 1, niet alleen omdat de psalmist deel uitmaakt van de 'zameling van bewarenden', maar bovenal omdat hij meebeweegt met de wil van Wezer: 'Maar in de wijzing van Wezer is zijn behagen' (Ps 1:2). 'Behagen' bestrijkt een breed affectief veld: verlangen en genoegen, interesse en betrokkenheid, graagte en bekommernis, genegenheid en welgevallen, verliefdheid en vriendschap, willen en vreugde, aangenaam vinden en verkiezen (Botterweck 1982:100-116). De grondbetekenis ligt in de innerlijke wilsbeweging die zich verwezenlijkt in gelieven, van harte willen, zich aangetrokken voelen, voorkeur hebben voor, verknocht en verkleefd zijn. In psalm 40 is 'behagen' dan ook: verknocht zijn met wat Wezer wil. Dit 'behagen' tekent exact 'de man' van psalm 1. Hij beweegt in alle opzichten mee met de wijzing van Wezer. Dit maakt hem tot 'knecht', geeft hem een profetische identiteit (Berges 1999:21-25). Hij luistert naar de wijzing van zijn Heer en leeft zijn aanspraak.

Het Psalter staat van meet af aan in de toonaard van het profetische 'hier mij', dat vanuit de ballingschap werd meegenomen als de ongeschreven wet van het Psalmboek. Dit beroep op de gehoorzame toe-eigening stempelt het Psalter tot profetische vroomheid.

\section{Het Psalter als meditatieboek}

Het 'murmeren' in de wijzing van Wezer intoneert niet slechts de liturgische thora in het spanningsveld van tempelpriesterschap en exilische profetie, het is tegelijkertijd de verbindende schakel tussen beide: mediteren in de thora van de wijsheid. Zo zegt psalm 143: 'Ik gedenk de dagen van voorlang, murmer in al jouw werken, in de maak van jouw handen verzucht $\mathrm{ik}^{\prime}$ (Ps 143:5). 'Murmeren' heeft hier de kleur van mediteren (zie ook Ps 77:12-13). De Griekse vertalers van de Septuagint vertaalden in diezelfde geest de term hagah met: mediteren (meletao), daarin gevolgd door de Vulgaat (meditari). Vanuit dit perspectief is de thora van het Psalter een religieus leerboek, een meditatieboek, de thora zoals Jezus Sirach die las: 'Alle wijsheid van de hoogste God ligt in het boek van zijn verbond besloten, de wijzing die Mozes ons geboden heeft, het erfdeel van Jakobs volk' (Jez Sir 24:23). De wijzing van Mozes is bron van wijsheid, murmerend voltrokken - in toegewijde studie en meditatie en biddend ontvangen:

Zijn hart gaat vol overgave vroeg al uit naar de Heer die hem gemaakt heeft.

En voor de Hoogste smeekt hij en opent zijn mond in gebeden en smeekt voor zijn zonden.

Wanneer de grote Heer het wil, wordt hij vervuld van een geest van opmerkzaamheid.

Hij laat woorden van zijn wijsheid opwellen en in gebeden erkent hij de Heer.

Hij geeft raad en kennis op de rechte wijze en zijn geheimen overdenkt hij.

Hij maakt het onderricht van zijn leer openbaar en beroemt zich op de wijzing van het verbond van de Heer. (Jez Sir 39:5-8)

Tweemaal is er sprake van 'gebeden' (tefilla), nader ingekleurd met smeken (eveneens tweemaal), overpeinzen en erkennen, dit alles vanuit 'de wijzing van het verbond' (Stadelmann 1980:221-232). Wezenlijk in de biddende bezinning is de genadige 'vervulling' met de geest van wijsheid die hem geschonken wordt, 'als de grote Heer het wil'.

Het Psalter als meditatief-biddend ontvangen wijsheid wordt bevestigd door handschriften die het Psalter voorop plaatsen in de Geschriften, onmiddellijk gevolgd door de wijsheidsboeken Job en Spreuken, in navolging van de Septuagint, Midden-Europese teksttradities en de meeste moderne uitgaven. De clustering van het Psalter met Job en Spreuken institueert een meditatief-biddende leeshouding. De existentiële vragen, zo dominant aanwezig in het Psalter, worden door Job en Spreuken (soms wordt Job zelfs nog voor het Psalter geplaatst) versterkt en in het centrum van de aandacht geplaatst.

\section{Tot slot}

Het Psalter, aldus Klaus Seybold, kan gezien worden als een archief 'waarin oude en nieuwe JHWH-getuigenissen tot 
een caleidoscoop van het geloof zijn opgeslagen' (Seybold 1986:30). Inderdaad, het Psalter lijkt op een caleidoscoop: eenvoudige ervaringen worden er veelvoudig in weerspiegeld waarbij verrassend regelmatige figuren te zien zijn die evenwel, bij de geringste beweging, weer nieuwe configuraties vormen. Een klein stootje, en het beeld is veranderd. Wonderlijk samenspel: het Psalter laat steeds nieuwe configuraties zien naar gelang de veranderende ervaring die tegen de kijker stoot. $\mathrm{Nu}$ eens een rijk opgetuigde liturgie, dan weer de naakte eenvoud van 'hier ben $\mathrm{ik}^{\prime}$, of tot bezinning stemmende gebeden. De configuraties verspringen bij iedere ingrijpende verschuiving van het spirituele perspectief. Abba Isaak had gelijk: 'Het gebed verandert steeds mee met de gesteltenis van de bidder. Niemand bidt tweemaal hetzelfde gebed' (Johannes Cassianus, Collationes 9.8).

\section{Erkenning \\ Concurrerende belangen}

Ik verklaar dat ik geen financiële of persoonlijke relaties heb die me ten onrechte hebben beïnvloed bij het schrijven van dit artikel.

\section{Literatuurverwijzingen}

Beckwith, R., 1985, The Old Testament canon of the New Testament church and its background in early Judaism, SPCK, London.

Berges, U., 1999, De Armen van het boek Jesaja, Kath. Univ. Nijmegen, Nijmegen.

Besnard, A., 1962, Le mystère du Nom, Cerf, Paris.

Beyse, K., 1986, ' $n$ ' $h$ ', in G. Anderson \& G. Botterweck (eds.), Theologisches Wörterbuch zum Alten Testament, Band V, pp. 117-119, Kohlhammer, Stuttgart.

Botha, P., 2005, 'Intertextuality and the interpretation of Psalm 1', Old Testament Essays 18(3), 503-520.

Botha, P. \& Potgieter, H., 2010, “"The word of Yahweh is right": Psalm 33 as a Torah Psalm', Verbum et Ecclesia 31/1, 8 pages. DOI: 10.4102/ve.v4131i4101.4431

Botterweck, G., 1982, 'chafats', in G. Anderson \& G. Botterweck (eds.), Theologisches Wörterbuch zum Alten Testament, Band V, pp. 100-116, Kohlhammer, Stuttgart.

Buber, M., 1962, Zur Verdeutschung des letzten Bandes der Schrift, Hegner, Köln-Olten. Buber, M., 1964, Ein Hinweis für Bibelkurse: Schriften zur Bibel (Werke II), pp. 1185-1186, Kösel-Verlag, München; Schneider, Heidelberg.

Buber, M. \& Rosenzweig, F., 1936, Die Schrift und ihre Verdeutschung, Schocken, Berlin.

Childs, B., 1979, Introduction to the Old Testament as Scripture, Fortress Press, Philadelphia, PA.

Crüsemann, F., 1969, Studien zur Formgeschichte von Hymnus und Danklied in Israel, Neukirchener Verlag, Neukirchen-Vluyn.

Fabry, H., 1995, 'Redactionele aanvulling bij het "torah" artikel van F. García López', in G. Anderson \& G. Botterweck (eds.), Theologisches Wörterbuch zum Alten Testament, Band VIII, p. 635, Kohlhammer, Stuttgart.

Fabry, H., Brunert, G., Kleer, M., Steins, G. \& Dahmen, U., 1993, 'sjir', in G. Anderson \& G. Botterweck (eds.), Theologisches Wörterbuch zum Alten Testament, Band VII, pp. 1259-1295, Kohlhammer, Stuttgart.

García López, F., 1995, 'torah', in G. Anderson \& G. Botterweck (eds.), Theologisches Wörterbuch zum Alten Testament, Band VIII, pp. 597-637, Kohlhammer, Stuttgart.

Gerleman, G., 1978, 'dabar', in G. Anderson \& G. Botterweck (eds.), Theologisches Wörterbuch zum Alten Testament, Band I, pp. 433-443, Kohlhammer, Stuttgart.

Gerleman, G. \& Ruprecht, E., 1978, 'darasj', in E. Jenni \& C. Westermann C. (eds.), Theologisches Handwörterbuch zum Alten Testament, Band I, pp. 460-467, Christian Kaiser Verlag, München.

Hossfeld, F. \& Zenger, E., 1993, Psalmen 1-50, Echter, Würzburg.

Hossfeld, F. \& Zenger, E., 2000, Psalmen 51-100, Herder, Freiburg.

Hossfeld, F. \& Zenger, E., 2008, Psalmen 101-150, Herder, Freiburg.

Johannes Cassianus, 1958, Conférences (VIII-XVII), tome II [Collationes], Cerf, Paris.

Johnston, P. \& Firth, D., 2005, Interpreting the Psalms: Issues and approaches, Intervarsity Press, Downers Grove, IL.
Kedar-Kopfstein, B., 1984, 'me'od', in G. Anderson \& G. Botterweck (eds.) Theologisches Wörterbuch zum Alten Testament, Band IV, pp. 611-613, Kohlhammer, Stuttgart.

Kraus, H., 1978, Psalmen, Band 1, 5. Auflage, Neukirchener Verlag des Erziehungsvereins, Neukirchen-Vluyn

Liedke, G. \& Petersen, C., 1979, 'torah', in E. Jenni \& C. Westermann C. (eds.), Theologisches Handwörterbuch zum Alten Testament, Band II, pp. 1032-1043, Christian Kaiser Verlag, München.

Lohfink, N. \& Bergman, J., 1973, “echad', in G. Anderson \& G. Botterweck (eds.), Theologisches Wörterbuch zum Alten Testament, Band I, pp. 210-218, Kohlhammer, Stuttgart.

Lombaard, C., 2014, 'Mysticism and understanding: Murmurs of meaning (fullness) Unheard silences of Psalm 1', Old Testament Essays (special edition for Harry van Rooy) 27(2), 472-488.

Millard, M., 1994, Die Komposition des Psalters, Mohr, Tübingen.

Negoita, A., 1977, 'hagah', in G. Anderson \& G. Botterweck (eds.), Theologisches Wörterbuch zum Alten Testament, Band II, pp. 343-347, Kohlhammer, Stuttgart.

Niles, D., 1974, 'The name of God in Israel's worship', Masters dissertation, Princeton University, Princeton, NJ.

North, R., 1977, 'chadasj', in G. Anderson \& G. Botterweck (eds.), Theologisches Wörterbuch zum Alten Testament, Band II, pp. 759-780, Kohlhammer, Stuttgart.

Ravasi, G., 1991, Il libro dei Salmi, Edizioni Dehoniane, Bologna.

Ridderbos, N., 1976, 'Psalmen und Kult', in P. Neumann (ed.), Zur Neueren Psalmenforschung, pp. 234-279, Wissenschaftliche Buchgesellschaft, Darmstadt.

Ridderbos, N., 1991, 'Psalmen en cultus', in C. van Ginkel \& P. van Midden (eds.), Psalmenstudie, pp. 234-279, Kok, Kampen.

Ringgren, H., 1977, 'Bemerking in het artikel "hagah" van A. Negoita', in G. Anderson \& G. Botterweck (eds.), Theologisches Wörterbuch zum Alten Testament, Band II, pp. 344-345, Kohlhammer, Stuttgart.

Rose, M., 1975, Der Ausschliesslichkeitsanspruch Jahwes, Kohlhammer, Stuttgart.

Safrai, S., 1980, Das jüdische Volk im Zeitalter des Zweiten Tempels, Neukirchener Verlag, Neukirchen-Vluyn.

Schmidt, W., 1977, 'dabar', in G. Anderson \& G. Botterweck (eds.), Theologisches Wörterbuch zum Alten Testament, Band II, pp. 89-133, Kohlhammer, Stuttgart.

Sellin, E. \& Fohrer, G., 1969, Einleitung in das Alte Testament, 11. Auflage, Quelle \& Meyer, Heidelberg.

Seybold, K., 1986, Die Psalmen: Eine Einführung, Kohlhammer, Stuttgart.

Seybold, K., 1996, Die Psalmen, Mohr, Tübingen

Seybold, K., 2003, Poetik der Psalmen, Kohlhammer, Stuttgart.

Stadelmann, H., 1980, Ben Sira als Schriftgelehrter, Mohr, Tübingen.

Stec, D., 2011, 'torah', in D. Clines, D. Stec \& J. de Roo (eds.), The dictionary of Classical Hebrew, vol. 8, pp. 612-616, Sheffield Phoenix Press, Sheffield.

Stolz, F., 1983, Psalmen im nachkultischen Raum, Theologischer Verlag, Zürich.

Tromp, N., 1980, Harmonie van contrasten: Beschouwingen over Exodus 34,6-7, Inaugurele rede Utrecht, Katholieke Theologische Hogeschool, s.n., Utrecht.

Von Rad, G., 1970, Weisheit in Israel, Neukirchener Verlag, Neukirchen-Vluyn.

Vries, M. de \& Winkel, L. te (eds.), 1991, Woordenboek der Nederlandsche taal, lemma 'wijzing', viewed 30 December 2017, from http://gtb.inl.nl/iWDB/search? actie $=$ article\&wdb=WNT\&id=M086375\&lemmodern=wijzing

Waaijman, K., 1984, Betekenis van de naam Jahwe, Kok, Kampen.

Waaijman, K., 1989, 'Gerechtigheid in de Schrift: Een spannend gebeuren', Speling 41(2), 79-89.

Waaijman, K., 2004, Mystiek in de psalmen, Ten Have, Baarn.

Waaijman, K., 2010, Handboek Spiritualiteit: Vormen, grondslagen en methoden, Ten Have, Kampen.

Waaijman, K., 2012, Hoe streelt jouw zegging mijn gehemelte, Ten Have, Kampen.

Waaijman, K., 2016, De getijden als spirituele rite, Titus Brandsma Memorial, Nijmegen.

Wagner, S., 1977, 'darasj', in G. Anderson \& G. Botterweck (eds.), Theologisches Wörterbuch zum Alten Testament, Band II, pp. 313-329, Kohlhammer, Stuttgart.

Wagner, S., 1982, 'jarah', in G. Anderson \& G. Botterweck (eds.), Theologisches Wörterbuch zum Alten Testament, Band III, pp. 921, Kohlhammer, Stuttgart.

Weber, B., 2007, 'Psalm 1 als Tor zur Tora JHWHs: Wie Ps 1 (und Ps 2) den Psalter an den Pentateuch anschliesst', Scandinavian Journal of the Old Testament 21(2), 179-200. https://doi.org/10.1080/09018320801896518

Weber, B., 2010, Von der Psaltergenese zur Psaltertheologie: Der nächste Schritt der Psalterexegese?! Einige grundsätzliche Überlegungen zum Psalter als Buch und Kanonteil, in E. Zenger (ed.), The composition of the Book of Psalms, pp. 733-744, Peeters, Leuven.

Westermann, C., 1962, 'Zur Sammlung des Psalters', Theologia Viatorum 8(2), 278-284.

Westermann, C., 1976, 'Anthropologische und theologische Aspekte des Gebets in den Psalmen', in P. Neumann (ed.), Zur neueren Psalmenforschung, pp. 452-468, Wissenschaftliche Buchgesellschaft, Darmstadt.

Westermann, C., 1978a, 'chadasj', in E. Jenni \& C. Westermann C. (eds.), Theologisches Handwörterbuch zum Alten Testament, Band I, pp. 524-530, Christian Kaiser Verlag, München. 
Westermann, C., 1978b, 'hll', in E. Jenni \& C. Westermann C. (eds.), Theologisches Handwörterbuch zum Alten Testament, Band I, pp. 493-502, Christian Kaiser Verlag, München.

Westermann, C., 1978c, 'jdh', in E. Jenni \& C. Westermann C. (eds.), Theologisches Handwörterbuch zum Alten Testament, Band I, pp. 674-682, Christian Kaiser Verlag, München.
Westermann, C., 1981, Hoofdlijnen van een theologie van het Oude Testament, 2e dr., Kok, Kampen.

Zenger, E., 1998, 'Der Psalter als Buch', in E. Zenger \& N. Lohfink (eds.), Der Psalter in Judentum und Christentum, Herder, Freiburg-Basel-Wien.

Zenger, E., 2010, 'Psalmenexegese und Psalterexegese: Eine Forschingsskizze', in E. Zenger (ed.), The composition of the Book of Psalms, pp. 17-65, Peeters, Leuven. 